DOI: 10.34185/1991-7848.itmm.2020.01.002

\title{
СИСТЕМНЫЙ ПОДХОД К ОБЕСПЕЧЕНИЮ НАДЕЖНОСТИ РАБОТЫ МНОГОКЛЕТЬЕВЫХ СТАНОВ
}

\author{
Баглай А.В., Кипин М.М. \\ ДП «Диамех-Украина», г. Харьков, Кременчуг, Украина
}

Аннотация. Рост объема производства, расширение сортамента продукции и улучшение его качества ведет к увеличению статических и динамических нагрузок, снижению долговечности и поломок прокатного оборудования усталостного характера. Комплексный подход $\mathrm{k}$ организации измерений и анализа вибрационных сигналов позволил разработать экспертную систему вибродиагностики «Корунд», которая обеспечивает постоянный контроль технического состояния клетей. В системе применены оригинальные алгоритмы измерений и анализа, учитывающие информацию о текущем техническом состоянии, циклах технологического процесса и особенностях нагружения прокатного оборудования. Диагностический модуль позволяет определить вид дефекта, степень его развития и рассчитать эксплуатационный ресурс узлов механизма. При этом диагностика выполняется как в процессе прокатки металла, так и в режиме холостого хода. Дополнительный функционал позволяет фиксировать время запаздывания сигналов на шестеренном, редукторном, моторном участках и судить о степени износа деталей механизма. Методика защитного мониторинга информирует персонал в режиме реального времени о возникновении внештатных ситуаций на прокатных клетях стана. Программное обеспечение имеет открытую архитектуру, легко конфигурируется под конкретную производственную задачу и работает с базами данных SQL и Oracle.

КлючевЫе слова: СИСТЕМА ВИБРАЦИОННОЙ ДИАГНОСТИКИ, МНОГОКЛЕТЬЕВОЙ СТАН, МЕТОДИКА ЗАЩИТНОГО МОНИТОРИНГА.

Техническое перевооружение в прокатном производстве Украины направлено на модернизацию действующих станов, внедрение новых технологий и систем автоматического управления на базе компьютеризированных систем. При этом значительная часть прокатного 
International scientific and technical conference Information Technologies in Metallurgy and Machine building - ITMM 2020

оборудования эксплуатируется десятилетиями, и ухудшение его технического состояния во многом связано с физическим старением. Этот факт выводит на первый план решение задачи поиска и обоснования методов и способов вибрационного диагностирования электродвигателей, редукторов, шестеренных клетей и валковых групп путем использования данных не только в холостом и установившемся режиме [1], но и в переходных процессах, прежде всего, в период заполнения очага деформации металлом и полосой при непрерывной группе клетей [2, 3].

Для эффективного решения задачи мониторинга и диагностики технического состояния оборудования многоклетьевых станов разработана автоматизированная диагностическая система «Корунд».

По результатам математического моделирования и натурных измерений на прокатных клетях были определены наиболее информативные параметры и выбраны оптимальные точки контроля вибрации. С учетом характера вибрационных переходных процессов работы клети (холостой ход, захват, прокатка, выброс) разработаны информативные признаки, наиболее тесно связанные с износом (дефектами) подшипников и зубчатых пар. Планомерная работа с массивами данных позволила разработать решающие правила для определения вида дефектов и степени их развития. Предусмотрен перекрестный анализ состояния подшипников и зубчатых зацеплений как в режиме холостого хода, так и в режиме прокатки. Выделенные области переходных процессов во временном сигнале используются для дополнительного анализа технического состояния клетей (рис. 1). В системе реализован алгоритм автоматического выбора участка сигнала для выполнения спектрального анализа в установившемся режиме работы клети. Кроме того, система учитывает режимы работы клети по сигналам, получаемых из заводской системы АСУ ТП, а результаты диагностики сортируются и хранятся в разных пакетах базы данных: для режима «прокатка» и для режима «холостой ход».

Синхронность измерения вибрации по всем каналам (от 7 до 11 датчиков) клети обеспечивает четкий контроль за временем запаздывания сигнала на всех участках: валков, шестеренной клети, редуктора, моторном участке. 


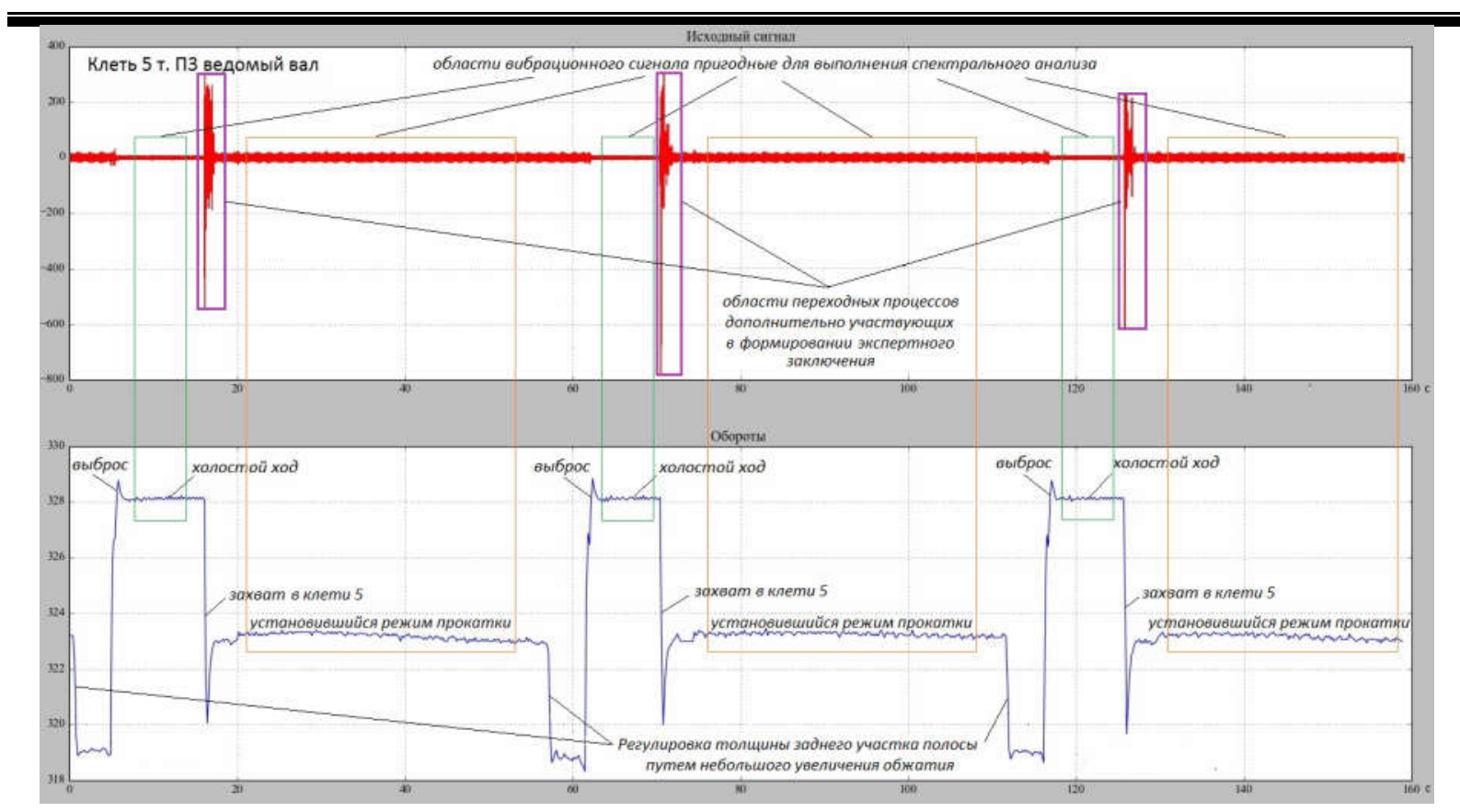

Рисунок 1 - Переходные процессы в клети № 5 стана 1680

Эти данные учитываются в определении степени развития дефектов и эксплуатационного ресурса узлов. В системе реализованы алгоритмы автоматических измерений, анализа, определения дефектов подшипников и зубчатых зацеплений и выдача рекомендаций, как для конкретного проанализированного узла, так и для клети в целом. Разработана Методика защитного мониторинга обеспечивающая своевременное информирование персонала о возникновении внештатной ситуации на прокатном оборудовании, что позволяет снизить вероятность развития вторичных дефектов. Локализация проблемы осуществляется на уровне клети стана, в виде световой сигнализации. Для этого в системе, в обязательном порядке, предусмотрено квитирование сигнализации о попадании оборудования в зону «Недопустимо» на контрольной панели оператора стана, с целью предотвращения пропуска аварийной сигнализации. Сигнал оператору стана о возникшей проблеме система выдает на 11 секунде, анализ произошедших аварий позволил определить оптимальное время реакции на развитие дефекта. Считается, если мгновенный всплеск вибрации (выше установленной нормы) держится в течение 10 секунд и не снижается до нормального состояния, значит произошло необратимое ухудшение технического состояния контролируемого узла. 
International scientific and technical conference Information Technologies in Metallurgy and Machine building - ITMM 2020

На тренде виброскорости (рис. 2) видно, что сначала вибрация редуктора высокоскоростного блока (стан А/С 400/215) 14.12.2018 г. находится в норме и составляет 1,3 - 1,6 мм/с, в 05:01:39 уровень вибрации вырос до 17,4 мм/с на одну секунду и снова снизился до 3,25 мм/с, однако в 05:01:41 произошел резкий рост вибрации до значений 139,74 - 197,22 мм/с, через 10 секунд сработал сигнал аварийной ситуации, и вибрация устойчиво держится в зоне технического состояния «Недопустимо» - начальная стадия развития аварийной ситуации. Затем в 05:01:51 начинается лавинообразный рост вибрации до значений 340 - 2045 мм/с, и через 2,5 минуты происходит разрушение дефектного подшипника.

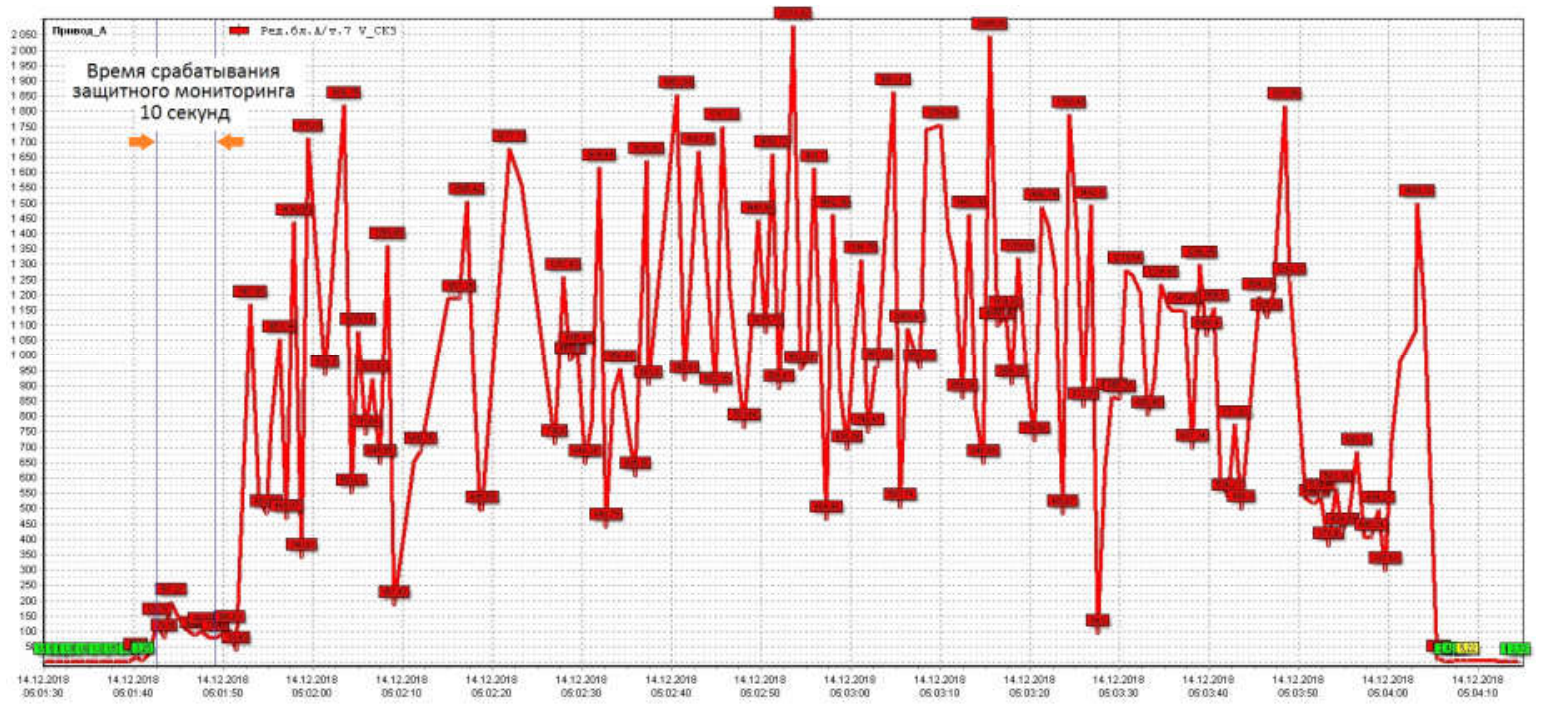

Рисунок 2 - Тренд виброскорости (секундные данные, без усреднения) в т. 7 редуктора высокоскоростного блока

При снижении нагрузки на клеть (например, изменении типа сортамента) уровень вибрации может снизиться, но дальнейшая эксплуатация клети крайне нежелательна, поскольку в агрегате присутствует узел с развитым дефектом, в конечной стадии развития, который в любой момент может выйти из строя.

Для обслуживающего персонала система автоматически формирует отчет с перечнем обнаруженных дефектов и рекомендаций по ремонтному воздействию или техническому обслуживанию прокатного оборудования (периодичность диагностирования клетей может быть выбрана от 20 минут до 8 часов). Система «Корунд» взаимодействует с базами данных SQL и Oracle. Структура программного обеспечения имеет открытую архитектуру и может 
Ministry of Education and Science of Ukraine

The National Metallurgical Academy of Ukraine, Dnipro, 17 - 19 March, 2020

быть скорректирована под конкретное технологическое оборудование.

Система предоставляет возможность в автоматическом режиме получать полноценную информацию о техническом состоянии оборудования прокатного стана, планировать время проведения технического обслуживания и ремонта оборудования, обнаруживать и устранять причины отказов, укреплять производственную дисциплину путем объективного контроля и своевременного планирования действий оперативного персонала.

\title{
Литература
}

1. Барков А. В., Баркова Н. А., Азовцев А. Ю. Мониторинг и диагностика роторных машин по вибрации : учеб. пособие. - СПб. : ГМТУ, 2012. - 159 с.

2. Веренев В. В., Большаков В. И., Путноки А. Ю., Коринь А. А., Мацко С. В. Диагностика и динамика прокатных станов : монография. - Днепр : ИМА-пресс, 2007. - 144 с.

3. Веренев В. В. Снижение динамических нагрузок и диагностика широкополосных станов в переходных режимах. - Никополь: СПД Фельдман О.О., 2014, - 203 с.

\section{INCLUSIVE APPROACH TO ENSURING THE LIABILITY OF WORK OF MULTISTAND MILL}

\section{Baglai Andrii, Kipin Mykhailo}

\begin{abstract}
The increase in production, the expansion of the product range and the improvement of its quality leads to an increase in quiescent and dynamical loads, a decrease of the durability and an increase of a number of rolling equipment breakdowns of fatigue nature. An integrated approach to the organisation of measurements and analysis of vibrational signals allowed to develop an expert system of vibration-based diagnostics "Korund", that provides a constant monitoring of the technical condition of the stands. Original measurement and analysis algorithms that take into account an information on the current technical condition, technical process cycles and loading characteristics of rolling equipment are employed in the system. The diagnostic module allows to determine the type of defect, the degree of its development and to calculate the working life of the machine components. Moreover, the diagnostic is performed both in the metal rolling process and in the idle state. The additional functionality allows to record the delay time of signals on the pinion-type, geared, motored sections and to evaluate
\end{abstract}


International scientific and technical conference

Information Technologies in Metallurgy and Machine building - ITMM 2020

the wear factor of the mechanism components. The method of safety monitoring informs employees about the occurrence of incidents at the rolling stands of the mill on a real-time basis. The software has an open architecture, is easily configured for a specific production task and can be integrated with SQL and Oracle databases.

Keywords: VIBRATION-BASED DIAGNOSTIC SYSTEM, MULTI-STAND MILL, SAFETY MONITORING TECHNIQUE.

\section{References}

1. Barkov A. V., Barkova N. A., Azovtsev A. Yu. Monitoring and diagnostics of rotor machines by vibration: tutorial. Saint-Petersburg: GMTU, 2012. $159 \mathrm{p}$

2. Verenev V. V., Bolshakov V. I., Putnoki A. Yu., Korin A. A., Matsko S. V. Diagnostics and dynamics of rolling mills: monograph. Dnepr: IMApress, 2007. 144 p.

3. Verenev V.V. Decrease in dynamic loads and diagnostics of broadband mills in transient conditions. - Nikopol: SPD Feldman O.O., 2014, - 203 p. 